THE POWER OF MAPS AND THE POLITICS OF BORDERS

Edited by

American Philosophical Society

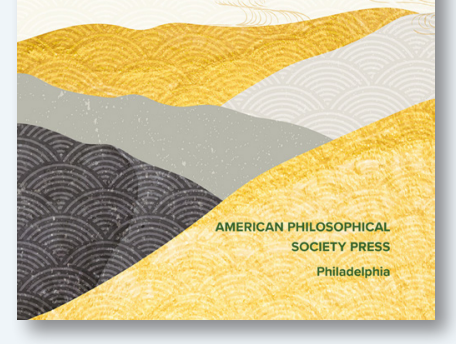

\section{THE POWER OF MAPS AND THE POLITICS}

OF BORDERS

Edited by the American Philosophical Society

The American Philosophical Society, 2019

242 pages

Paperback: \$37.00, ISBN 978-1-60618-104-1

Review by: Maya Daurio (she/her), University of British Columbia
This COllection of PAPERS was edited and published by the American Philosophical Society and grew out of a 2019 conference and exhibition exploring maps and mapping in relation to the production of political and ideological borders in the early American republic. For the purposes of the exhibition, this era was defined as being between 1780-1816, although certain chapters of the book encompass maps and events significantly before and after those dates. Both the exhibition and the book illustrate how maps can be used to understand the structures of meaning and ways of knowing contemporary to this particular historical period. Together, the collected papers convey the power bestowed upon physical and cartographic boundary-making as it was mobilized in treaty negotiations between sovereign nations, in disputes between territorial governments, or in classifying the natural environment for the purpose of administering tracts of land. While the significance of maps in shaping narratives and abetting the goals of colonial powers is not a new subject, the twelve authors in this collection offer fresh perspectives on the cartographic delineation of space during a period of frenetic territorial expansion in early America.

Most of the authors are historians, and each situates a particular cartographic project-whether a specific map, a surveying expedition, or a boundary negotiation - within a specific spatiotemporal and historical context. In so doing, they shed new light on historical events and relations or previously under-examined archival materials in order to derive broader insights about territoriality, sovereignty, and equality, and to expand earlier understandings about spatial knowledge production, both colonial and Indigenous. This approach provides a valuable contribution to our knowledge of cartographic epistemologies in relation to the formation of the American republic, and illuminates how maps wield uneven power, based both on the authority bestowed upon them and on the ways in which they are used to harness control.

The general role of maps and mapping in the early American republic is framed in the Introduction: "Unpacking the Meaning of Maps, Power, and Boundaries," by independent scholar Nicholas Gliserman, who describes how important maps were in the social, cultural, and political formation of the nation. Gliserman highlights how this volume uniquely illustrates the ways maps can be used to address spatially oriented questions in the early life of the nation, such as "what would the shape of the nation be, or what was America's place in the world" (1), underscoring their value in understanding the history of this period. Derek Kane O'Leary, of the University of South Carolina, offers a particularly illustrative example of the way that maps were mobilized to legitimate certain territorial claims and discount others in his chapter "Archival Lines, Historical Practice, and the Atlantic Geopolitics behind the 1842 Webster-Ashburton Treaty." In it, he describes the way a map uncovered from French archives was imbued with historical significance during negotiations for the 1842 Treaty (which settled several disputes along the US-Canadian border) to justify the Americans' position, 
and was subsequently dehistoricized by treaty negotiator and US Secretary of State Daniel Webster to downplay its role once negotiations were completed (186). In her chapter, “'Suitable for the Parlor of an American': The Legacy of Major Sebastian Bauman's Map of the Siege of Yorktown," Kate McKinney, assistant curator of maps and prints at Colonial Williamsburg, discusses a map used to convey a particular narrative of American nationhood. This 1782 map depicted a glorified version of the battle between the British and American colonists at Yorktown: one which served to legitimize American statehood and to symbolize a distinct White American identity-an identity inaccessible to those Black Virginians who fought on the British side and who were left to fend for themselves after British surrender (18). One persistently recurring theme throughout the book is the intimate connection between the American colonists' desire to be free from British rule and the colonial project's attachment to the financial security afforded by institutional slavery, which further encouraged appropriation of Indigenous lands.

The linkage between slavery and land acquisition is explored in George Gallwey's "Mapping New Empires and Old: Albert Gallatin and the Cartographic Infrastructure of the Early Republic," in which he examines the career of the Geneva-born surveyor and diplomat to frame a clear analysis of the intersection of finance, territory, and the colonial project (47). Gallwey, of Harvard University, references Gallatin's 1836 Map of the Indian Tribes of North America, illustrating the chronology of territorial expansion across the continent by simultaneously depicting languages spoken on the east coast from the 1600s and on the west coast from the 1800 s, respectively. Gallatin intended the map to help preserve knowledge about so-called "ancient cultures" (51), with the implication that Indigenous languages would soon be extinct.

In contrast to other maps of this era, Gallatin's acknowledges the presence of Indigenous peoples, however problematically. Julie Reed, of The Pennsylvania State University, in her chapter, "Thinking Multidimensionally: Cherokee Boundaries Above, Below, and Beyond," demonstrates that other Euro-American cartographers in the eighteenth and nineteenth centuries expediently represented Indigenous spaces as unoccupied wilderness landscapes open for settlement (59). Reed distinguishes between the conceptual limitations of the two-dimensional maps produced by Euro-Americans and the multidimensional Cherokee mapping and iconography located in caves across the southeast, places which figure prominently in Cherokee cosmology. Reed's chapter demonstrates the need to consider how Cherokee geographies can help us understand Cherokee place-making before, during, and after European settlement in the Native South.

The appetite for land characterized the relationships between American and European colonizers with competing territorial interests and their interactions with the various Indigenous nations, including the Osage, Chickasaw, and Cherokee. The Cherokee are the focus of three chapters in this collection that provide refreshing historical analyses of Indigenous conceptualizations of space and these groups' various strategies of resistance to colonial settlement and expansion. Reed observes that European settlers in what is today the American South failed to account for the multidimensional conceptual constructions of space held by that region's Cherokee inhabitants, and that our understanding of that historical moment is limited by a dearth of Indigenous accounts in the historical record (66). Austin Stewart, of Lehigh University, draws attention to the development over time of Cherokee cartographic epistemologies in his chapter "Wielding the Power of Mapping: Cherokee Territoriality, Anglo-American Surveying, and the Creation of Borders in the Early Nineteenth-Century West." Early Cherokee maps, such as the Catawba Deerskin Map of 1721, centered on social and political relationships between places and the trade routes connecting them, rather than depicting boundaries differentiating occupied territories (75). Western Cherokee emigrants to the Arkansas Valley later appropriated both the techniques and aims of Anglo-American surveying and cartography to resist colonization of their lands and, in turn, to stake land claims that would lead to the dispossession of other Indigenous nations, specifically the Osage. Similarly, Lucas Kelley, of Valparaiso University, describes the various manifestations of Cherokee and Chickasaw resistance to colonial land grabs in his chapter "Clear Boundaries or Shared Territory: Chickasaw and Cherokee Resistance to American Colonization, 1792-1816." These included not only acts of force but also ideas and deployments of both colonial and Indigenous legal frameworks, including land demarcation through surveys (95).

While some of the chapters illuminate underexploredto the non-historian at least-episodes of, or characters in, early American mapmaking, land administration, or surveying expeditions (see, for example, the chapters by Spanagel, Hardy, and Smith), other chapters uncover the 
stories behind familiar delimitations of nationhood and American geography. For example, the Mason-Dixon line is today simply understood as the line between those states in the South which allowed slavery and those in the North which did not, but its geographic history reveals a more complex story. Agnès Trouillet, of the Université Paris 10 Nanterre, expands our understanding of the history behind this dividing line in "Elusive Hinlopen, or the Cape's role in Protracting the Boundary Dispute Between Pennsylvania and Maryland." Trouillet highlights how early British conceptions of, and rule over, its colonial territory in North America in the seventeenth century were ill-defined on the ground, leading to territorial disputes between provinces. The proprietors for Pennsylvania and Maryland, in this example, disagreed over the boundaries between their provinces-and thus the geographic limits of their authority and the proper allocation of tax revenue to each. The dispute arose due to various British (mis) understandings about the geography of North America, whereby they defined jurisdictions by lines of latitude, often without reference to neighbouring grants, and not infrequently resulting in overlapping boundaries (133). The Mason-Dixon line was named after the two astronomers who were eventually hired to resolve the eight-decade long dispute between the families of the original proprietors William Penn and Lord Baltimore by surveying the line that ultimately divided not only Pennsylvania and Maryland, but also the North from the South (147).

In a departure from the approach employed by the authors of the other chapters - that is, of analyzing a map or a surveying expedition in order to contextualize a certain historical period-Billy Smith and a team of researchers at Montana State University mobilized GIS and historical records to reimagine a 1797 map of Philadelphia. Their map included the presence of women and of enslaved people-both typically absent from maps and censuses of that period. Smith uses the revamped map to contrast the route of a hypothetical carriage journey taken by Martha Washington through the streets of that city, with the more circuitous one required of Ona- a person enslaved by Martha-who accompanied her on foot. Mapping the differentiated mobility of these two women highlights Philadelphia's role in growing emancipatory movements and the critical role of Black residents during the yellow fever epidemic of 1793-during which they became defacto caretakers and administrators of a city abandoned by Whites who could afford to leave. Smith's chapter, "Mapping Inequality, Resistance, and Solutions in Early
National Philadelphia," is also unique in its narrower geographic focus on the historical and unequal settlement patterns in one city, in a book largely expressive of colonial reach over extensive tracts of land.

This collection illustrates the high stakes involved in early American colonial government claims to land. Federal authorities encountered resistance from the many Indigenous nations whose lands they coopted, and competed with the colonizing endeavours of multiple European countries, including the British, Dutch, Spanish, and French. As David Spanagel, of Worcester Polytechnic Institute, explains in "Putting Science to the Test: Initiating the World's Longest Unfortified Boundary," this competition erupted in three boundary dispute wars between the United States and the United Kingdom between 1754 and 1814. Following the 1814 Treaty of Ghent-which ended the War of 1812 and affirmed the United States and British North American borders as those of the Treaty of 1793-America and Great Britain undertook to discover and mark where their allocated territories actually lay in space. These efforts disrupted Indigenous sovereignty and a period of relatively peaceful cohabitation between Indigenous and non-Indigenous peoples in the Great Lakes region (192). Although decades had elapsed since the 1793 treaty had established that a border existed, it had never been physically measured and was therefore poorly administered. Spanagel is among several contributors - including Pearson and Reed-who highlight how the physical measurement and division of land between the claims of colonizing governments was particularly effective in undermining Indigenous authority, even where those governments had declared their claim to that same land long before.

How cartography, and, more broadly, scientific endeavors such as land surveying and geological expeditions, lent authority to geopolitical claims over territory and legitimized the representation of rights to the land emerges as a key theme in many chapters. The assembly, archiving, and categorization of information about flora and fauna, geographic features, waterways, and even the ocean floor, rendered land knowable to its colonial administrators. Penelope Hardy, of the University of WisconsinLa Crosse, in "Finding the History of the World at the Bottom of the Ocean: Hydrography, Natural History, and the Sea in the Nineteenth Century," details the interdisciplinary and transnational research by zoologists, naturalists, and chemists on ocean bottom deposits during 
the remarkable voyage of the Royal Navy vessel HMS Challenger in its circumnavigation of the world between 1872 and 1876 (123). Evolving sounding technology in the mid-1800s enabled the scientists to collect flora, fauna, and sediment from the ocean floor, from which to derive hypotheses about terrestrial geology and with which to chart the geographies of ocean depths, particularly in the Atlantic Ocean between North America and Europe (120).

The production of maps and reports which emerged from the frenetic collection of information during surveying and geological expeditions sometimes strategically depicted lands as uninhabited as the basis for territorial claims of legitimacy. These documents could then be used to assert jurisdiction in international land claim disputes, to administer taxes, to facilitate further land settlement, and to diminish Indigenous sovereignty. Jackson Pearson, of Texas Christian University, describes the production of such a map in "William Darby's Map of Louisiana and the Extension of American Sovereignty over the 'Neutral Ground' in the Louisiana-Texas Borderland, 1806-1821.” From 1812 to 1815, Darby undertook two surveying expeditions to the contested Louisiana-Texas borderlands, an area classified by the United States and Spain as neutral ground belonging to neither government. His detailed attribution of the physical landscape lent validity to the map he would eventually publish, which was referenced in negotiations allowing American officials to exercise authority over the "Neutral Ground" and facilitate the project of American expansionism.

The Power of Maps and The Politics of Borders will engage a range of disciplinary audiences, including historians, geographers, cartographers, and anthropologists. Those interested in historical maps will enjoy its diverse examples of early American cartography, ranging from a map depicting the territories defined in the 1808 Treaty of Fort Clark (80) to a map of the Cherokee Nation by one of its delegates in 1785 (97). With the exception of a few, most of the maps are small and hard to see, which is unfortunate for a book that so eloquently traces the essential role of mapping and charting in the formation of the early American republic. The contributors to the collection offer compelling examples of how cartography, technologies, and archives were wielded to advance early American colonial expansion and served to normalize "the assumption that political space should be tightly defined and delineated" (6). 